\title{
Serum glucose and risk of cancer: a meta-analysis
}

\author{
Danielle J Crawley ${ }^{1,6^{*}}$, Lars Holmberg ${ }^{1,2,3}$, Jennifer C Melvin ${ }^{1}$, Massimo Loda ${ }^{4,5}$, Simon Chowdhury ${ }^{6}$, \\ Sarah M Rudman ${ }^{6}$ and Mieke Van Hemelrijck
}

\begin{abstract}
Background: Raised serum glucose has been linked to increased risk of many solid cancers. We performed a meta-analysis to quantify and summarise the evidence for this link.

Methods: Pubmed and Embase were reviewed, using search terms representing serum glucose and cancer. Inclusion and exclusion criteria focused on epidemiological studies with clear definitions of serum glucose levels, cancer type, as well as well-described statistical methods with sufficient data available. We used $6.1 \mathrm{mmol} / \mathrm{L}$ as the cut-off for high glucose, consistent with the WHO definition of metabolic syndrome. Random effects analyses were performed to estimate the pooled relative risk (RR).

Results: Nineteen studies were included in the primary analysis, which showed a pooled RR of 1.32 ( $95 \%$ Cl: $1.20-1.45$ ). Including only those individuals with fasting glucose measurements did not have a large effect on the pooled RR (1.32 (95\% Cl: 1.11-1.57). A stratified analysis showed a pooled RR of 1.34 (95\% Cl: 1.02-1.77) for hormonally driven cancer and 1.21 (95\% Cl: 1.09-1.36) for cancers thought to be driven by Insulin Growth Factor-1.

Conclusion: A positive association between serum glucose and risk of cancer was found. The underlying biological mechanisms remain to be elucidated but our subgroup analyses suggest that the insulin- IGF-1 axis does not fully explain the association. These findings are of public health importance as measures to reduce serum glucose via lifestyle and dietary changes could be implemented in the context of cancer mortality.
\end{abstract}

Keywords: Glucose, Cancer, Metabolic syndrome, Meta-analysis, Diabetes

\section{Background}

Diabetes mellitus is a risk factor for many chronic diseases including cardiovascular disease and cancer. People with diabetes are 2 -fold more likely to die from cancer than those without [1]. Therefore, it is thought that pre-diagnostic elevated blood glucose levels are associated with risk of cancer [2-4]. Several epidemiological studies have investigated this association. The largest being a Korean cohort study of over one million men and women found a hazard ratio for all solid cancers of 1.22 (95\% CI: 1.16-1.27) for men in the fifth quintile compared to the first quintile [5].

Despite the growing evidence for an association between diabetes and carcinogenesis [6], the mechanism by which raised glucose contributes to risk of cancer is not fully

\footnotetext{
* Correspondence: Danielle.crawley@kcl.ac.uk

'King's College London, School of Medicine, Division of Cancer Studies,

Cancer Epidemiology Group, London, UK

${ }^{6}$ Department of Oncology, Guy's \& St Thomas' NHS Foundation Trust, London, UK

Full list of author information is available at the end of the article
}

established [7]. The insulin - insulin growth factor (IGF)-1 axis is a commonly suggested pathway. It is thought that insulin resistance, which impairs the action of insulin and occurs in individuals with type 2 diabetes or metabolic syndrome, leads to prolonged hyperinsulinaemia. This decreases the production of IGF-binding proteins, which consequently results in raised IGF-1 levels and cellular changes leading to carcinogenesis via increased mitosis and reduced apoptosis [8]. It is, however, important to note that hyperinsulinemia during the early stages of diabetes may play a role in carcinogenesis independent of IGF-1 [9].

Another suggested pathway between glucose and risk of cancer is the reduced hepatic production of sex hormone binding globulin (SHBG) following prolonged hyperinsulinaemia [8]. This leads to an increase of available sex hormones, such as oestrogen and testosterone, which can drive carcinogenesis in hormonal sensitive cancers like postmenopausal breast or prostate cancers [8].

Elevated glucose can result in a state of chronic inflammation which changes the cytokine micro-environment 
and leads to an increase of cytokines such as interleukin 6 (IL-6) [10], tissue necrosis factor alpha (TNF- $\alpha$ ) [11,12] and vascular endothelial growth factor (VEGF) [13]. These changes can lead to an increase in tumour cell motility, invasion and even tumour metastasis [14,15].

Finally, glucose may have a direct role in cancer development as it is a key nutrient. It is needed for proliferating cells and several types of tumour cells have been shown to have up-regulated glucose transporters [16].

Given the above-suggested pathways and the increasing prevalence of diabetes and cancer, this meta-analysis aims to summarize and quantify the existing evidence for a link between raised serum glucose and risk of all solid cancers. Using data from epidemiological studies on adult participants whose serum glucose levels and cancer diagnoses were assessed, this study aims to answer the question whether there is a higher risk of solid cancer in those with raised glucose levels, compared to those with normal levels.

\section{Methods}

This meta-analysis was conducted following the PRISMA statement for completing systematic reviews and meta-analyses [17].

\section{Literature search strategy}

A computerised literature search of databases (Pubmed search followed by an Embase search) to identify full text and abstracts published within the last fifteen years, which included only adult human subjects was performed. "Grey literature" such as abstracts, letters, articles presented at relevant conferences and meetings, was also reviewed. The search was done with and without MESH terms (serum glucose, blood glucose, cancer, neoplasm). We also conducted cancer-specific searches for prostate, breast, colorectal, oesophageal, gastric, pancreatic, liver, lung, ovarian, endometrial, cervical, testicular, bladder, melanoma, brain, thyroid and head and neck cancers. All references of the selected articles were checked, including hand searches.

The final articles were chosen based on the following set of inclusion criteria: the publication pertained to an epidemiological study which measured circulating serum levels of glucose (fasting or non fasting); the reference level of high glucose was clearly defined; risk of a non-fatal solid cancer (any type) was assessed as an outcome; the analytical methods were well-described with sufficient and relevant data available; predominantly non-diseased adult study populations were used; a minimum of 20 cases were included. Studies measuring glucose only after an oral glucose load were excluded. The literature review and data collection was conducted by DC and reviewed by MVH.

Initially, titles were reviewed to assess whether they met inclusion criteria. Titles that indicated the study met these criteria progressed to an abstract review. Upon inclusion after this step, the full manuscript was thoroughly checked to evaluate inclusion and exclusion criteria. Additional studies were considered from grey literature and hand searches $(\mathrm{N}=18)$. Unpublished data on glucose and risk of breast, prostate, and colorectal cancer was also obtained from the MECAN group, allowing us to use this large dataset in the analysis of all cancers [18]. Figure 1 provides more detailed information regarding the exclusion process. More specifically, 12 studies were excluded because incident cancer risk was not the main outcome of interest [17,19-29], ten studies did not provide the data to calculate number of cases with high and normal glucose levels [4,30-38], 13 studies were using data which was already used in another included publication [39-51], one study was cross-sectional and addressed correlations instead of risks [52], one study included less than 20 cases [53], one was not published in English [54], 16 did not provide data on serum glucose levels prior to cancer diagnosis [33,55-70], and one study was not available through our different data resources [71].

The following details were recorded for each study: author, year of publication, country where study was undertaken, sex of participants, age range, type of cancer, type of study, fasting or non fasting glucose measurements and number of cases and total subjects for each glucose range. To allow for comparison all values in conventional units $(\mathrm{mg} / \mathrm{dl})$ were converted into SI units $(\mathrm{mmol} / \mathrm{L})$ [72].

\section{Statistical methods}

The association between serum glucose and cancer risk was evaluated by calculating the pooled relative risk (RR) with a random effects model to allow for possible heterogeneity between studies. A cut-off of $>6.1 \mathrm{mmol} / \mathrm{L}$ was used to define high glucose, consistent with values used in WHO definition of metabolic syndrome [73]. The included studies all used different cut off points for

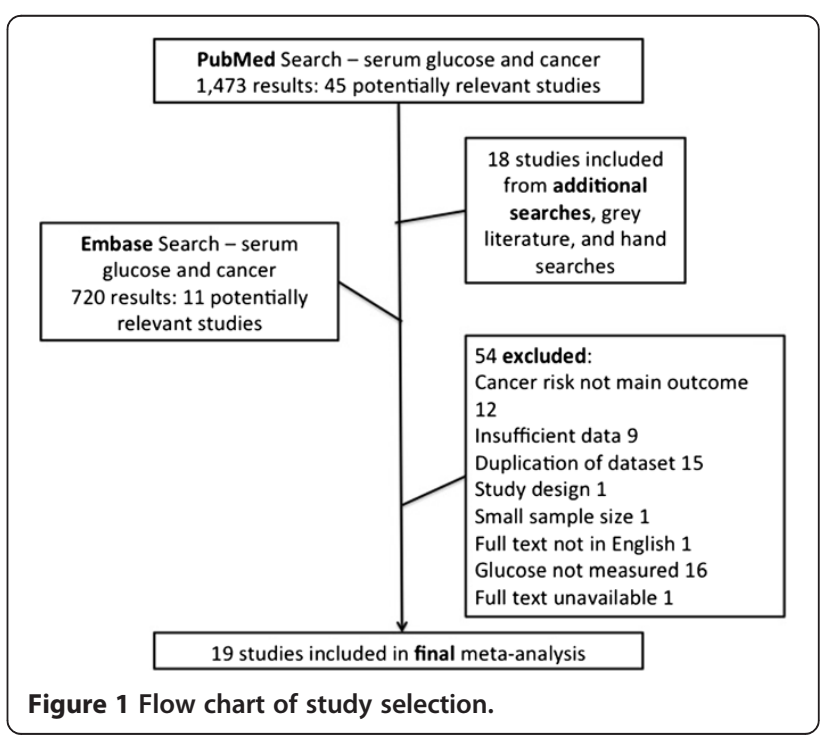


Table 1 Summary of study characteristics included in primary analysis

\begin{tabular}{|c|c|c|c|c|c|c|c|c|c|c|}
\hline Author/Year & Country & Sex & $\begin{array}{l}\text { Cancer (s) } \\
\text { included }\end{array}$ & $\begin{array}{l}\text { Timing of } \\
\text { measurement } \\
\text { glucose }\end{array}$ & $\begin{array}{l}\text { Method for glucose } \\
\text { assessment }\end{array}$ & $\begin{array}{l}\text { Study } \\
\text { type }\end{array}$ & Cases & Age range & Adjusted for & Main finding \\
\hline $\begin{array}{l}\text { Yun et al. } \\
2012[77]\end{array}$ & Korea & Male & Prostate & Fasting & $\begin{array}{l}\text { Hitachi } 7600 \\
\text { automatic chemical } \\
\text { analyser using } \\
\text { hexokinase method }\end{array}$ & $\begin{array}{l}\text { Case } \\
\text { control\# }\end{array}$ & 166 & 66.4 (mean) & Age, BMl & $\begin{array}{l}\text { OR for } 2^{\text {nd }} \text { and } 3^{\text {rd }} \text { tertile compared } \\
\text { to } 1^{\text {st }} \text { tertile: } 1.63 \text { (95\% Cl: 0.92-2.88) } \\
\text { and } 1.70(95 \% \text { Cl: } 0.91-3.18)\end{array}$ \\
\hline $\begin{array}{l}\text { Albanes et al. } \\
2009 \text { [78] }\end{array}$ & Finland & Male & Prostate & Fasting & $\begin{array}{l}\text { Hitachi } 912 \text { Chemistry } \\
\text { Analyzer using the } \\
\text { hexokinase reagent }\end{array}$ & $\begin{array}{l}\text { Case } \\
\text { cohort }\end{array}$ & 100 & $50-69$ & Age, BMl & $\begin{array}{l}\text { OR for } 2^{\text {nd }}, 3^{\text {rd }} \text {, and } 4^{\text {th }} \text { quartile } \\
\text { compared to } 1^{\text {st }} \text { quartile: } 1.33(95 \% \\
\text { Cl: } 0.72-2.48), 0.95(95 \% \text { Cl: } 0.46-1.86) \text {, } \\
\text { and } 1.43(95 \% \text { Cl: } 0.76-2.68)\end{array}$ \\
\hline $\begin{array}{l}\text { Chung et al. } \\
2006 \text { [79] }\end{array}$ & Korea & Both & Colorectal & Fasting & $\begin{array}{l}\text { Enzymatic } \\
\text { colorimetric test }\end{array}$ & $\begin{array}{l}\text { Case } \\
\text { control\# }\end{array}$ & 105 & $35-75$ & $\begin{array}{l}\text { Age, sex, BMl, triglycerides, } \\
\text { cholesterol }\end{array}$ & $\begin{array}{l}\text { OR for } 2^{\text {nd }} \text { and } 3^{\text {rd }} \text { tertile compared } \\
\text { to } 1^{\text {st }} \text { tertile: } 2.0 \text { (95\% Cl: 0.9-4.4) and } \\
3.0 \text { ( } 95 \% \text { Cl: 0.9-9.8) }\end{array}$ \\
\hline $\begin{array}{l}\text { Jee et al. } 2005 \\
\text { Male [5] }\end{array}$ & Korea & Male & All Cancers & Fasting & Not specified & Cohort & 37759 & 45.3 (mean) & $\begin{array}{l}\text { Age, age squared, amount of } \\
\text { smoking, alcohol use }\end{array}$ & $\begin{array}{l}\text { HR for } 2^{\text {nd }}, 3^{\text {rd }}, 4^{\text {th }} \text {, and } 5^{\text {th }} \text { quintile } \\
\text { compared to } 1^{\text {st }} \text { quintile: } 1.01(95 \% \\
\text { Cl: } 0.99-1.04), 1.13(95 \% \text { Cl: } 1.09-1.17) \text {, } \\
1.16 \text { (95\% Cl: } 1.08-1.24) \text {, and } 1.22 \\
(95 \% \text { Cl: } 1.16-1.27)\end{array}$ \\
\hline $\begin{array}{l}\text { Jee et al. } 2005 \\
\text { Female [5] }\end{array}$ & Korea & Female & All Cancers & Fasting & Not specified & Cohort & 16074 & 49.6 (mean) & $\begin{array}{l}\text { Age, age squared, amount of } \\
\text { smoking, alcohol use }\end{array}$ & $\begin{array}{l}\text { HR for } 2^{\text {nd }}, 3^{\text {rd }}, 4^{\text {th }} \text {, and } 5^{\text {th }} \text { quintile } \\
\text { compared to } 1^{\text {st }} \text { quintile: } 1.02(95 \% \\
\text { Cl: } 0.99-1.06), 1.03 \text { (95\% Cl: } 0.96-1.10) \text {, } \\
1.03 \text { (95\% Cl: } 0.93-1.13) \text {, and } 1.15 \\
(95 \% \text { Cl: } 1.01-1.25)\end{array}$ \\
\hline $\begin{array}{l}\text { Hsing et al. } \\
2003 \text { [80] }\end{array}$ & China & Male & Prostate & Fasting & $\begin{array}{l}\text { Radioimmunoassay } \\
\text { with sensitivity limit } \\
\text { of } 0.5 \mathrm{ng} / \mathrm{mL}\end{array}$ & $\begin{array}{l}\text { Case } \\
\text { control* }\end{array}$ & 128 & $\mathrm{~N} / \mathrm{S}$ & Age, total calories, BMI & $\begin{array}{l}\text { OR for } 2^{\text {nd }} \text { and } 3^{\text {rd }} \text { tertile compared } \\
\text { to } 1^{\text {st }} \text { quartile: } 0.81 \text { (95\% Cl: } 0.46- \\
1.44) \text {, and } 1.68 \text { ( } 95 \% \text { Cl: } 1.01-2.80)\end{array}$ \\
\hline $\begin{array}{l}\text { Wulaningsih } \\
\text { et al. } 2013 \text { [81] }\end{array}$ & Sweden & Both & All Cancers & Non specified & $\begin{array}{l}\text { Enzymatically with a } \\
\text { glucose oxidase/ } \\
\text { peroxidase method }\end{array}$ & Cohort & 1021 & $20>$ & $\begin{array}{l}\text { Age, gender, socioeconomic status, } \\
\text { fasting,co-morbidities }\end{array}$ & $\begin{array}{l}\text { HR: } 1.08 \text { (95\% Cl: 1.02-1.14) per } \\
\text { standardized log of glucose }\end{array}$ \\
\hline $\begin{array}{l}\text { Cust et al. } \\
2007[82]\end{array}$ & $\begin{array}{l}\text { Western } \\
\text { Europe }\end{array}$ & Female & Endometrial & Non specified & $\begin{array}{l}\text { Enzymatic } \\
\text { colorimetric test }\end{array}$ & $\begin{array}{l}\text { Case } \\
\text { control* }\end{array}$ & 284 & 59.9 (mean) & $\begin{array}{l}\text { Study centre, menopausal status, } \\
\text { age, time of day of blood collection, } \\
\text { fasting status, phase of menstrual } \\
\text { cycle (pre menopausal) }\end{array}$ & $\begin{array}{l}\text { OR for } 2^{\text {nd }}, 3^{\text {rd }}, \text { and } 4^{\text {th }} \text { quartile } \\
\text { compared to } 1^{\text {st }} \text { quartile: } 1.01(95 \% \\
\text { Cl: } 0.58-1.74), 1.59(95 \% \text { Cl: } 0.89-2.83) \text {, } \\
\text { and } 1.62(95 \% \text { Cl: } 0.89-2.95)\end{array}$ \\
\hline $\begin{array}{l}\text { Limburg et al. } \\
2006[83]\end{array}$ & Finland & Male & Colorectal & Fasting & $\begin{array}{l}\text { Hitachi } 912 \text { Chemistry } \\
\text { Analyzer using the } \\
\text { hexokinase reagent }\end{array}$ & $\begin{array}{l}\text { Case } \\
\text { cohort }\end{array}$ & 134 & $50-69$ & $\begin{array}{l}\text { Smoking pack years, BMI, protein } \\
\text { intake, fat intake, fibre intake, alcohol } \\
\text { consumption, caloric intake, history } \\
\text { of DM, occupational physical activity }\end{array}$ & $\begin{array}{l}\text { HR for } 2^{\text {nd }}, 3^{\text {rd }} \text {, and } 4^{\text {th }} \text { quartile } \\
\text { compared to } 1^{\text {st }} \text { quartile: } 1.19(95 \% \\
\text { Cl: } 0.58-2.43), 1.95(95 \% \text { Cl: } 0.97-3.91) \text {, } \\
\text { and } 1.65 \text { (95\% Cl: } 0.78-3.49)\end{array}$ \\
\hline $\begin{array}{l}\text { Stolzenberg- } \\
\text { Solomon et al. } \\
2005 \text { [84] }\end{array}$ & Finland & Male & Pancreatic & Fasting & $\begin{array}{l}\text { Assay performed on a } \\
\text { chemical analyser }\end{array}$ & $\begin{array}{l}\text { Case } \\
\text { cohort }\end{array}$ & 169 & $52-69$ & Age, years of smoking and BMI & $\begin{array}{l}\text { HR for } 2^{\text {nd }}, 3^{\text {rd }} \text {, and } 4^{\text {th }} \text { quartile } \\
\text { compared to } 1^{\text {st }} \text { quartile: } 1.15(95 \% \\
\text { Cl: } 0.66-2.02), 1.49 \text { ( } 95 \% \text { Cl: } 0.86-2.59) \text {, } \\
\text { and } 1.69 \text { (95\% Cl: } 0.97-2.94)\end{array}$ \\
\hline $\begin{array}{l}\text { Yamada } 1998 \\
\text { et al. [85] }\end{array}$ & Japan & Both & Colorectal & Fasting & $\begin{array}{l}\text { Enzymatically using } \\
\text { commercially } \\
\text { available kits }\end{array}$ & $\begin{array}{l}\text { Case } \\
\text { control* }^{*}\end{array}$ & 129 & $34-73$ & $\begin{array}{l}\text { Age, sex, BMl, smoking, alcohol } \\
\text { consumption }\end{array}$ & $\begin{array}{l}\text { OR for } 2^{\text {nd }}, 3^{\text {rd }} \text {, and } 4^{\text {th }} \text { quartile } \\
\text { compared to } 1^{\text {st }} \text { quartile: } 1.0 \text { ( } 95 \% \text { Cl: } \\
0.6-1.7), 0.7 \text { (95\% Cl: } 0.3-1.5) \text {, and } 2.0 \\
(0.9-4.4)\end{array}$ \\
\hline
\end{tabular}


Table 1 Summary of study characteristics included in primary analysis (Continued)

\begin{tabular}{|c|c|c|c|c|c|c|c|c|c|c|}
\hline $\begin{array}{l}\text { Schoen et al. } \\
1999 \text { [86] }\end{array}$ & USA & Both & Colorectal & Fasting & & Cohort & 102 & $65>$ & Age, sex, physical activity & \\
\hline $\begin{array}{l}\text { Zhang et al. } \\
2010 \text { [87] }\end{array}$ & China & Female & Endometrial & Fasting & $\begin{array}{l}\text { Abbott Aeroset TM } \\
\text { fully Automatic } \\
\text { Biochemical Analyzer }\end{array}$ & $\begin{array}{l}\text { Case } \\
\text { control\# }\end{array}$ & 942 & N/A & Menopausal status, BMl & $\begin{array}{l}\text { OR: } 4.34 \text { (95\% Cl: } 3.48-5.42) \text { for high } \\
\text { versus low serum glucose levels }\end{array}$ \\
\hline $\begin{array}{l}\text { Gunter et al. } \\
2009 \text { [88] }\end{array}$ & USA & Female & Breast & Fasting & $\begin{array}{l}\text { Assay with sensitivity } \\
\text { of } 0.5 \mathrm{mg} / \mathrm{dL}\end{array}$ & $\begin{array}{l}\text { Case } \\
\text { cohort }\end{array}$ & 835 & $50-79$ & $\begin{array}{l}\text { Age, race, alcohol consumption, } \\
\text { smoking, FHx breast cancer, parity, } \\
\text { age at menarche, age at first childs } \\
\text { birth,use of OCP, NSAIDs, HRT, } \\
\text { educational attainment, endogenous } \\
\text { estrodiol levels, BMI, physical activity }\end{array}$ & $\begin{array}{l}\text { HR for } 2^{\text {nd }}, 3^{\text {rd }}, \text { and } 4^{\text {th }} \text { quantile } \\
\text { compared to } 1^{\text {st }} \text { quantile: } 1.14(95 \% \\
\text { Cl: } 0.82-1.59), 0.99(95 \% \text { Cl: } 0.70-1.38) \text {, } \\
\text { and } 0.92 \text { (95\% Cl: 0.65-1.29) }\end{array}$ \\
\hline $\begin{array}{l}\text { Sieri et al. } \\
2012 \text { [89] }\end{array}$ & Italy & Female & Breast & Fasting & $\begin{array}{l}\text { Enzymatic UV test } \\
\text { using a fully } \\
\text { automated system } \\
\text { with sensitivity of } \\
0.04 \mathrm{mmol} / \mathrm{L}\end{array}$ & $\begin{array}{l}\text { Case } \\
\text { control* }\end{array}$ & 356 & $35-69$ & $\begin{array}{l}\text { Age, education, age at first birth, age } \\
\text { at menarche, parity, FHx breast } \\
\text { cancer, OCP, breastfeeding, alcohol } \\
\text { intake, smoking }\end{array}$ & $\begin{array}{l}\text { OR for } 2^{\text {nd }}, 3^{\text {rd }}, \text { and } 4^{\text {th }} \text { quartile } \\
\text { compared to } 1^{\text {st }} \text { quartile: } 1.18(95 \% \\
\text { Cl: } 0.84-1.66), 1.29(95 \% \text { Cl: } 0.89-1.86) \text {, } \\
\text { and } 1.63(95 \% \text { Cl: } 1.14-2.32)\end{array}$ \\
\hline $\begin{array}{l}\text { Gunter et al. } \\
2008[44]\end{array}$ & USA & Female & Colorectal & Fasting & $\begin{array}{l}\text { Assay with sensitivity } \\
\text { of } 0.5 \mathrm{mg} / \mathrm{dL}\end{array}$ & $\begin{array}{l}\text { Case } \\
\text { cohort }\end{array}$ & 438 & $50-79$ & Age & $\begin{array}{l}\text { HR for } 2^{\text {nd }}, 3^{\text {rd }} \text {, and } 4^{\text {th }} \text { quantile } \\
\text { compared to } 1^{\text {st }} \text { quantile: } 0.94(95 \% \\
\text { Cl: } 0.66-1.34), 0.91 \text { ( }(95 \% \text { Cl: } 0.63-1.30) \text {, } \\
\text { and } 1.16 \text { (95\% Cl: } 0.83-1.63)\end{array}$ \\
\hline $\begin{array}{l}\text { Van Hemelrijck } \\
\text { et al. } 2011 \text { [90] }\end{array}$ & Sweden & Both & Renal & Mixed & $\begin{array}{l}\text { Enzymatically with a } \\
\text { glucose- } \\
\text { oxidaseperoxidase } \\
\text { method }\end{array}$ & Cohort & 958 & 55.4 (mean) & $\begin{array}{l}\text { Age, gender, creatinine, triglycerides, } \\
\text { total cholesterol, fasting status, SES }\end{array}$ & $\begin{array}{l}\text { HR for } 2^{\text {nd }}, 3^{\text {rd }}, \text { and } 4^{\text {th }} \text { quartile } \\
\text { compared to } 1^{\text {st }} \text { quartile: } 0.97(95 \% \\
\text { Cl: } 0.77-1.21), 1.09 \text { (95\% Cl: } 0.88-1.35) \text {, } \\
\text { and } 1.19(95 \% \text { Cl: } 0.97-1.46)\end{array}$ \\
\hline $\begin{array}{l}\text { Van Hemelrijck } \\
\text { et al. } 2011[91]\end{array}$ & Sweden & Male & Prostate & Mixed & $\begin{array}{l}\text { Enzymatically with a } \\
\text { glucose- } \\
\text { oxidaseperoxidase } \\
\text { method }\end{array}$ & Cohort & 5112 & $20-80$ & $\begin{array}{l}\text { Fasting status,triglyceride and total } \\
\text { cholesterol quartile, SES, time btw } \\
\text { measurement and cohort entry }\end{array}$ & $\begin{array}{l}\text { HR for } 2^{\text {nd }}, 3^{\text {rd }} \text {, and } 4^{\text {th }} \text { quartile } \\
\text { compared to } 1^{\text {st }} \text { quartile: } 0.93(95 \% \\
\text { Cl: } 0.86-1.01), 0.93 \text { ( } 95 \% \text { Cl: } 0.85-1.01) \text {, } \\
\text { and } 0.87(95 \% \text { Cl: } 0.81-0.94)\end{array}$ \\
\hline $\begin{array}{l}\text { Chao et al. } \\
2011 \text { [92] }\end{array}$ & China & Male & Liver & Fasting & $\begin{array}{l}\text { Automatic dry- } \\
\text { chemical analyzer }\end{array}$ & $\begin{array}{l}\text { Case } \\
\text { cohort }\end{array}$ & 124 & $30-65$ & $\begin{array}{l}\text { Age, smoking, alcohol consumption, } \\
\text { FHx of HCC, HBV viral load, HCV } \\
\text { genotype ,HbeAg status, BCP double } \\
\text { mutations }\end{array}$ & $\begin{array}{l}\text { HR for } 2^{\text {nd }} \text { and } 3^{\text {rd }} \text { tertile compared } \\
\text { to } 1^{\text {st }} \text { tertile: } 1.40(95 \% \mathrm{Cl}: 0.80-2.45) \\
\text { and } 2.37(95 \% \mathrm{Cl}: 1.12-5.04)\end{array}$ \\
\hline $\begin{array}{l}\text { Stocks et al. } \\
2009[18]\end{array}$ & $\begin{array}{l}\text { Western } \\
\text { Europe }\end{array}$ & Male & All Cancers & Mixed & $\begin{array}{l}\text { Mixture of non- } \\
\text { enzymatic, serum/en- } \\
\text { zymatic, and plasma/ } \\
\text { enzymatic }\end{array}$ & Cohort & 18621 & 44.7 (mean) & Age, BMl, smoking status & $\begin{array}{l}\text { HR for } 2^{\text {nd }}, 3^{\text {rd }}, 4^{\text {th }} \text {, and } 5^{\text {th }} \text { quintile } \\
\text { compared to } 1^{\text {st }} \text { quintile: } 1.07(95 \% \\
\text { Cl: } 0.90-1.25), 1.10 \text { (95\% Cl: } 0.93-1.29) \text {, } \\
1.18 \text { (95\% Cl: } 1.02-1.37) \text {, and } 1.18 \\
\text { ( } 95 \% \text { Cl: } 1.00-1.37)\end{array}$ \\
\hline $\begin{array}{l}\text { Stocks et al. } \\
2009[18]\end{array}$ & $\begin{array}{l}\text { Western } \\
\text { Europe }\end{array}$ & Female & All Cancers & Mixed & & Cohort & 11664 & 45 (mean) & Age, BMl, smoking status & $\begin{array}{l}\text { HR for } 2^{\text {nd }}, 3^{\text {rd }}, 4^{\text {th }} \text {, and } 5^{\text {th }} \text { quintile } \\
\text { compared to } 1^{\text {st }} \text { quintile: } 0.87(95 \% \\
\text { Cl: } 0.70-1.07), 0.90 \text { (95\% Cl: } 0.73-1.10) \text {, } \\
\text { 1.18 (95\% Cl: } 0.97-1.42) \text {, and } 1.29 \\
\text { (95\% Cl: } 1.07-1.59)\end{array}$ \\
\hline
\end{tabular}


glucose levels, some used tertiles, others quartiles or quintiles. For the sake of this analysis all data was dichotomised into 'high' and 'normal' as close to the $6.1 \mathrm{mmol} / \mathrm{L}$ cut off as possible by combining groups above and below this level.

An initial meta-analysis was performed using all studies. Potential heterogeneity was assessed with weighted forest plots, which display the relative risk estimate of cancer depending on glucose level. Potential publication bias was assessed with a contour enhanced funnel plot, as well as Beggs Test [41,42]. We also performed stratified analyses by study type and sex. We then conducted cancer-specific analyses for prostate, breast, and colorectal cancer, as these were the most commonly investigated cancers. We also conducted a secondary analysis excluding those studies which did not specify the fasting status of the glucose samples. Given the suggested complex aetiology between diabetes, glucose, and cancer, we additionally conducted stratified analyses based on potential underlying mechanisms - below referred to as hormone-driven and IGF-1-driven [74,75]. Although the identification of which cancers are driven by the IGF-1 axis, is not entirely elucidated, the cancers for which the most consistent supporting evidence is available are prostate, colorectal and breast cancer $[9,52,75,76]$. Hence, here we considered these as 'IGF-1 driven' cancers. Breast, endometrial and prostate cancers were also combined for a separate subgroup of 'hormone driven' cancers [23,30,55]. All analyses were performed on STATA version 12.0.

\section{Results}

The Pubmed search resulted in a total of 1,473 studies, 45 of which were deemed as initially relevant. A further 11 were identified via an Embase search and 18 from hand searches and grey literature, resulting in a total of 74 potentially relevant papers. Using the above-defined criteria, 55 were excluded (Figure 1).

A total of 19 studies were included in the primary analysis: six cohort, six case cohort, three hospital-based case-control, and four nested case-control studies. Nine studies were

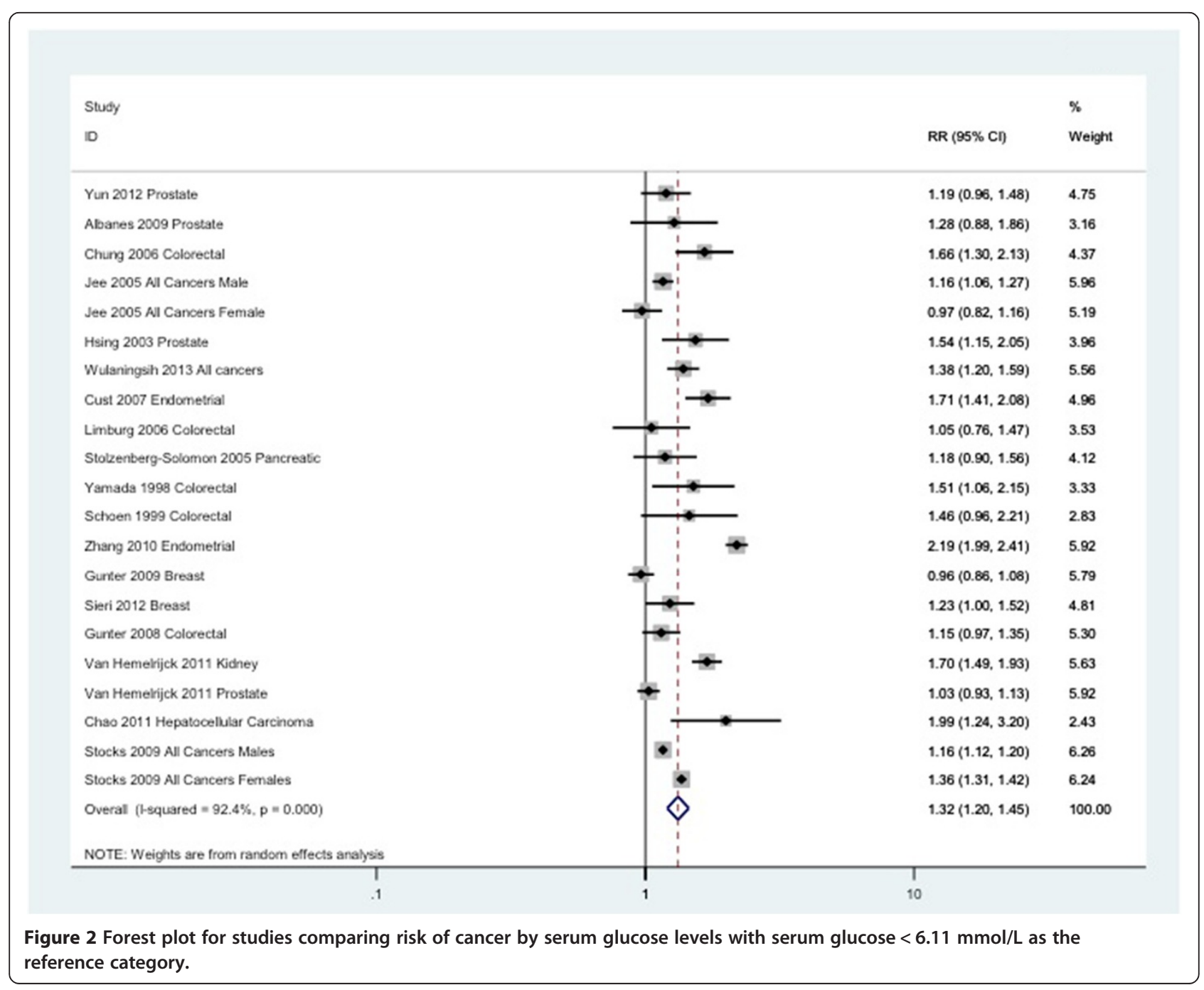


conducted in Europe, seven in Asia and three in the USA. Three studies presented data on all solid cancers, five on colorectal cancer, four on prostate cancer, two on breast cancer, two on endometrial cancer and one paper each for pancreatic, renal and hepatocellular cancers (Table 1).

The random effects analysis comparing overall cancer risk by serum glucose levels showed a pooled relative risk (RR) of 1.32 (95\% CI: 1.20 - 1.45) for high versus normal levels of serum glucose (Figure 2). The $\mathrm{I}^{2}$ statistic showed heterogeneity $\left(\mathrm{I}^{2}=92 \%\right.$; $\left.\mathrm{P}<0.05\right)$, even though every individual estimate indicated a positive association. Hence, we conducted a 'remove one' analysis to gauge each study's impact; the $\mathrm{I}^{2}$ statistic did not fall below $85 \%$. Next, we conducted a sensitivity analysis using studies which included 'all cancers' as the outcome versus those with site specific outcomes. The heterogeneity remained high and the RR did not change drastically. When looking at "All cancers" as an outcome, the RR was $1.21(95 \%$ CI: 1.09 1.34) with and $\mathrm{I}^{2}$ of $92 \%$. When combining all site-specific cancers as an outcome, the RR was 1.38 (95\% CI: 1.161.63) with an $\mathrm{I}^{2}$ of $92 \%$. Tumour-specific analyses were performed for the three most commonly studied cancers and resulted in pooled relative risks of 1.09 (95\% CI: 0.95-
1.25), 1.35 (95\% CI: $1.21-1.51)$ and 1.14 (95\% CI: $1.04-$ 1.26), for breast, colorectal and prostate cancer, respectively. The related $\mathrm{I}^{2}$ statistic was $74 \%$ for breast, $57 \%$ for colorectal, and $53 \%$ for prostate.

A stratified analysis by study type showed similar pooled RRs for cohort studies, case-cohort/nested case-control studies and hospital-based case-control studies (Figure 3): 1.24 (95\% CI: 1.13-1.37), 1.29 (95\% CI: 1.11-1.51), and 1.64 (95\% CI: 1.11-2.43). The $\mathrm{I}^{2}$ statistic was $92 \%, 76 \%$, and $93 \%$, respectively (Figure 4 ).

The overall pooled RR was 1.17 (95\% CI: 1.09-1.25) for men and 1.32 for women (95\% CI: 1.06-1.63). Studies where it was not possible to stratify by sex showed a pooled RR of 1.55 (95\% CI: 1.40-1.71). The I $\mathrm{I}^{2}$ statistic for these sex-stratified analyses was $48 \%$ for men, $96 \%$, for women and $19 \%$ where it was not possible to stratify by sex. Including only those with fasting glucose measurements did not have a large effect on the pooled RR either (RR: 1.32 (95\% CI: 1.11-1.57). The $\mathrm{I}^{2}$ statistic was $92 \%$.

The pooled RR for hormonally driven cancers was 1.34 (95\% CI: 1.02-1.77; I': 96\%) versus 1.41 (95\% CI: 1.20-1.66; $\left.I^{2}: 69 \%\right)$ for the non-hormonally driven cancers. IGF-1driven cancers showed a pooled RR of 1.21 (95\% CI: 1.09-

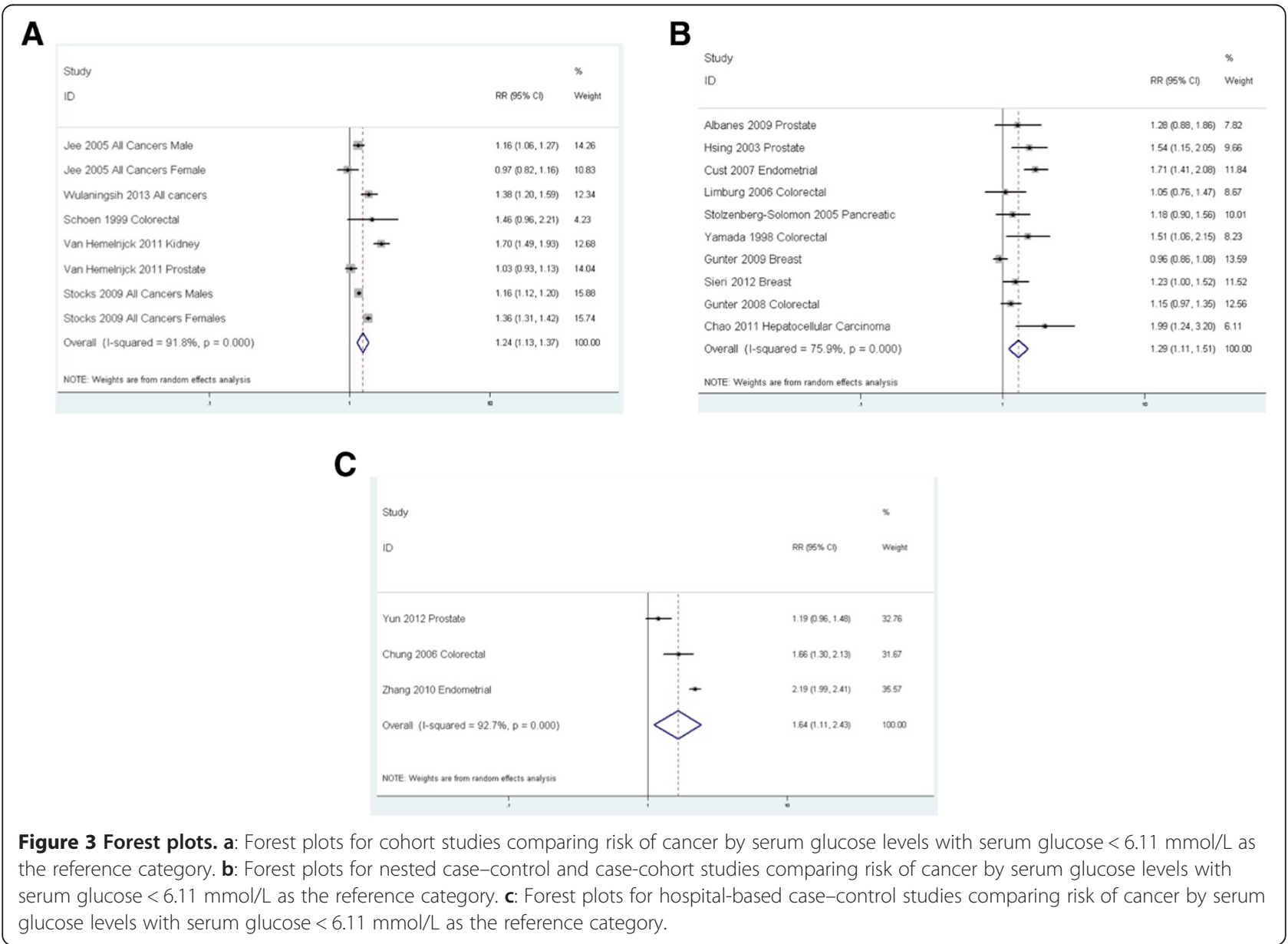




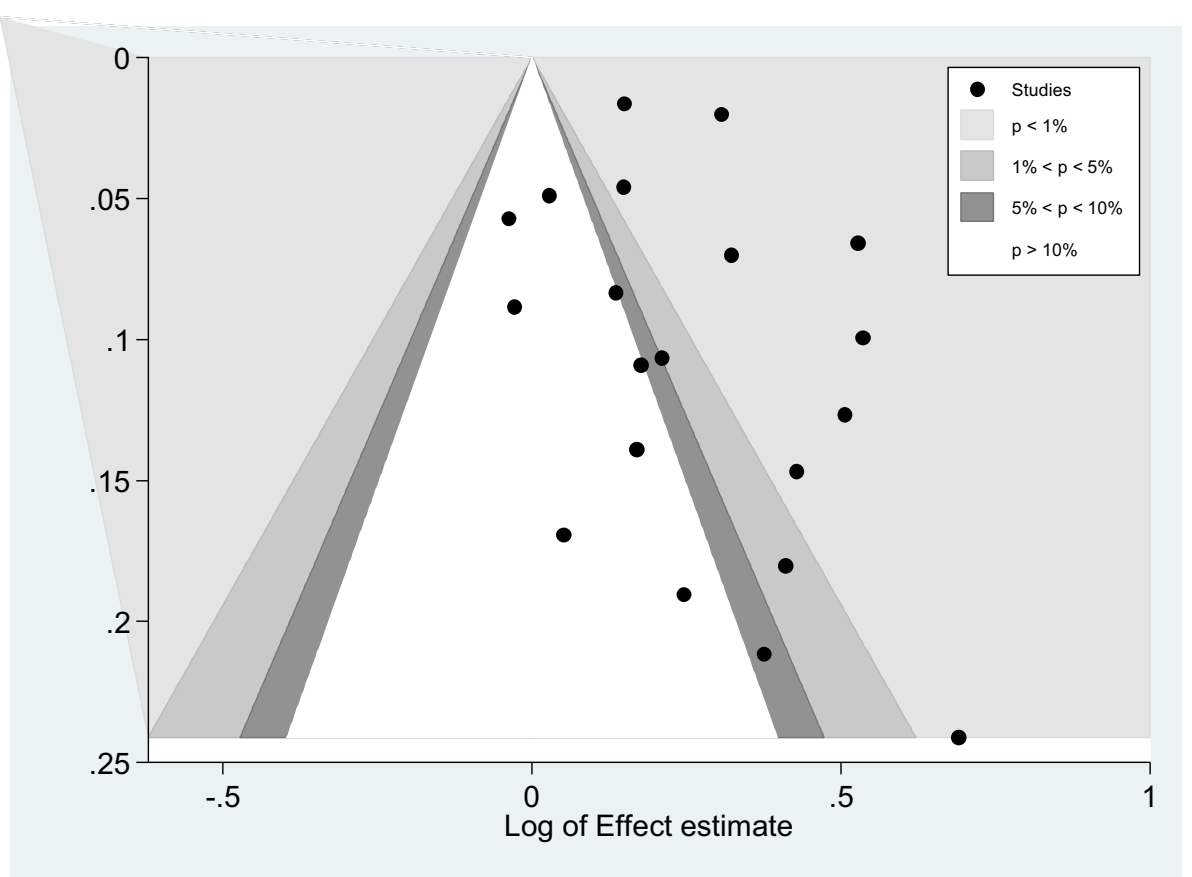

Figure 4 Contour enhanced funnel plot for meta-analysis comparing risk of cancer by serum glucose levels with serum glucose $<6.11 \mathrm{mmol} / \mathrm{L}$ as the reference category.

$1.36 ; \mathrm{I}^{2}: 67 \%$ ) versus 1.73 (95\% CI: $\left.1.40-2.12 ; \mathrm{I}^{2}: 85 \%\right)$ for those not thought to be driven by IGF.

When assessing publication bias, the funnel plot showed an area of missing studies which includes regions of both low and high statistical significance suggesting that both studies that showed a non-significantly and significantly inverse association between glucose and cancer were missing. Therefore, under the assumption that studies are being suppressed because of a mechanism based on twosided p-values, publication bias cannot be accepted as the only cause of funnel asymmetry.

\section{Discussion}

This is the first meta-analysis examining the association of serum glucose and cancer risk. We found a consistent positive association, which was not altered strongly by sex, study type, or cancer type.

As previously described, several molecular mechanisms have been postulated in an effort to explain the association between glucose and carcinogenesis. The insulin - IGF-1 axis is the most commonly suggested pathway [93]. Our results showed a weaker association for IGF-1 driven cancers than the overall association or non-hormonally driven cancers, suggesting that if the insulin- IGF- 1 axis does play a role it is likely to be as part of a more complex molecular mechanism.

Another proposed mechanism is an increased availability of sex hormones caused by a reduction of SHBG in the presence of hyperinsulinaemia [7,94]. However, our meta-analysis showed a similar association between elevated serum glucose and risk of hormonally and nonhormonally driven cancers. This suggests that this is not the only underlying mechanism for the link between glucose and cancer. It is possible that other mechanisms, i.e. chronic inflammation [10-12] or direct actions of glucose [16], may also be playing a role.

To our knowledge this is the first comprehensive meta-analysis looking at epidemiological studies of serum glucose levels and cancer risk. Existing metaanalyses to date focused on the association between serum glucose levels and a specific type of cancer $[4,76]$. A breast cancer-specific study including ten cohort studies found that the association between serum glucose levels and risk of breast cancer was small in nondiabetic subjects (pooled RR: 1.11 (95\% CI: 0.98-1.25) [4]. The direction of this study is consistent with our findings, however our meta-analysis focused on high serum glucose levels as defined by the WHO definition for metabolic syndrome so that we also included potential diabetic subjects. Thus, when investigating serum levels of glucose, it is also important to consider diabetes. A bladder cancer-specific study showed that diabetes was associated with a 30\% increased risk (95\% CI: 1.18-1.43), which is consistent with the direction of the association found for serum glucose and cancer in our meta-analyses [76]. Other cancer types which also show a positive association with diabetes include pancreatic, endometrial, breast and colorectal cancer [20-22,95], 
however an inverse association has been observed for prostate cancer [91]. The latter must be interpreted with caution as diabetics have higher morbidity and mortality from other diseases. There may be competing risks masking their risk of prostate cancer [96]. However, it is important to note that diabetes is a slightly different exposure than serum levels of glucose as diabetic treatments may normalise glucose levels and potentially also affect risk of cancer [43].

We made every effort to include all relevant publications available to date through various sources, including grey literature, and the two main online databases (Pubmed and Embase). We were able to also access unpublished data from the MECAN group enabling us to include this large cohort of over 500,000 subjects [18]. In addition, clearly defined objective criteria for exposure, outcome, and other study characteristics were specified $a$ priori. One limitation of our study is the heterogeneity between the different categorization methods for glucose ranges across the include studies. We tried to overcome this by combining the different categories as similarly as possible and believe this cannot significantly affect our findings. Nevertheless, this made it not possible in the current meta-analysis to make a distinction between pre-diabetes and diabetes. The overall results showed a rather large amount of heterogeneity, as suggested by the $\mathrm{I}^{2}$ statistic. All of our sensitivity and subgroup analyses showed consistent findings in terms of direction of the association, while the heterogeneity remained high. Only when we conducted tumour specific analysis, the $\mathrm{I}^{2}$ statistic reduced. This suggests that heterogeneity is most likely explained by combining studies with different outcomes. However, the consistent finding of a positive association in all our analyses supports the robustness of our findings. Six of the studies included, either had mixed or did not specify fasting status. However, exclusion of these studies did not alter the association observed. A further limitation is the lack of information regarding the diagnosis of diabetes, use of oral hypoglycaemics or insulin in those included in the studies. Future research including adjustment for components such as age, cancer treatment, diabetes (or its treatments), or BMI would be useful in confirming the importance of raised glucose in carcinogenesis. All studies included were soundly designed and executed epidemiological studies, which clearly defined their methodology. However, the size of the studies did vary considerably. The two largest studies $[5,18]$ did account for well over half of the cases included, but they represent a Korean and European population which we believe can be broadly applicable to all patient populations. Limitations reported by the individual studies overlap widely. They include, having only localised cancer as an outcome, small sample size, specific demographic groups only (i.e. smokers only), lack of information on diabetes and obesity and all but one study [81] used single measurements of glucose for their analysis.

\section{Conclusions}

A positive association was found between serum glucose levels and risk of cancer. The heterogeneity observed between studies calls for more translational studies investigating how serum glucose is associated with carcinogenesis. However, given there were seven million deaths from cancer worldwide in 2011 and it is estimated that more than a third were attributable to modifiable risk factors [97], these findings are of public health importance as measures to reduce serum glucose via lifestyle and dietary changes could be implemented to reduce risk of cancer.

\begin{abstract}
Abbreviations
BMI: Body mass index; 95\% Cl: 95\% confidence interval; IGF-1: Insulin growth factor -1; SHBG: Sex hormone binding globulin; IL-6: Interleukin 6; TNF-alpha: Tissue necrosis factor alpha; VEGF: Vascular endothelial growth factor; WHO: World Health Organisation; RR: Relative risk.
\end{abstract}

\section{Competing interests}

The authors declare that they have no competing interests.

\section{Authors' contributions}

Study design: DC, MVH. Statistical analysis and interpretation: DC, JM, MVH. Manuscript preparation: DC. Critical review of manuscript: DC, SR, SC, ML, LH, $\mathrm{JM}, \mathrm{MVH}$. All authors read and approved the final manuscript.

\section{Acknowledgments}

This research was supported by the Experimental Cancer Medicine Centre at King's College London and also by the National Institute for Health Research (NIHR) Biomedical Research Centre based at Guy's and St Thomas' NHS

Foundation Trust and King's College London. The views expressed are those of the author(s) and not necessarily those of the NHS, the NIHR or the Department of Health.

The authors would also like to thank Dr Tanja Stocks, who kindly provided data from the MECAN study to be incorporated in this meta-analysis.

\section{Author details}

'King's College London, School of Medicine, Division of Cancer Studies, Cancer Epidemiology Group, London, UK. ${ }^{2}$ Regional Cancer Centre, Uppsala-Örebro, Uppsala University Hospital, Uppsala, Sweden. ${ }^{3}$ Department of Surgical Sciences, Uppsala University, Uppsala, Sweden. ${ }^{4}$ Department of Pathology, Harvard Medical School, Boston, MA, USA. ${ }^{5}$ Pathology, Dana-Farber Cancer Institute, Boston, MA, USA. ${ }^{6}$ Department of Oncology, Guy's \& St Thomas' NHS Foundation Trust, London, UK.

Received: 29 April 2014 Accepted: 9 December 2014 Published: 19 December 2014

\section{References}

1. Emerging Risk Factors C, Seshasai SR, Kaptoge S, Thompson A, Di Angelantonio E, Gao P, Sarwar N, Whincup PH, Mukamal KJ, Gillum RF, Holme I, Njølstad I, Fletcher A, Nilsson P, Lewington S, Collins R, Gudnason V, Thompson SG, Sattar N, Selvin E, Hu FB, Danesh J: Diabetes mellitus, fasting glucose, and risk of cause-specific death. N Engl J Med 2011, 364(9):829-841.

2. Hirakawa $Y$, Ninomiya T, Mukai N, Doi Y, Hata J, Fukuhara M, Iwase M, Kitazono T, Kiyohara Y: Association between glucose tolerance level and cancer death in a general Japanese population: the Hisayama Study. Am J Epidemiol 2012, 176(10):856-864.

3. Dankner R, Chetrit A, Segal P: Glucose tolerance status and 20 year cancer incidence. Isr Med Assoc J: IMAJ 2007, 9(8):592-596.

4. Boyle P, Koechlin A, Pizot C, Boniol M, Robertson C, Mullie P, Bolli G, Rosenstock J, Autier P: Blood glucose concentrations and breast cancer risk in women without diabetes: a meta-analysis. Eur J Nutr 2013, 52(5):1533-1540.

5. Jee SH, Ohrr H, Sull JW, Yun JE, Ji M, Samet JM: Fasting serum glucose level and cancer risk in Korean men and women. JAMA 2005, 293(2):194-202. 
6. Esposito K, Chiodini P, Colao A, Lenzi A, Giugliano D: Metabolic syndrome and risk of cancer: a systematic review and meta-analysis. Diabetes Care 2012, 35(11):2402-2411.

7. Arcidiacono B, liritano S, Nocera A, Possidente K, Nevolo MT, Ventura V, Foti $D$, Chiefari E, Brunetti A: Insulin resistance and cancer risk: an overview of the pathogenetic mechanisms. Exp Diabetes Res 2012, 2012:789174.

8. Renehan AG, Frystyk J, Flyvbjerg A: Obesity and cancer risk: the role of the insulin-IGF axis. Trends Endocrinol Metab: TEM 2006, 17(8):328-336.

9. Stattin P, Bylund A, Rinaldi S, Biessy C, Dechaud H, Stenman UH, Egevad L, Riboli E, Hallmans G, Kaaks R: Plasma insulin-like growth factor-I, insulinlike growth factor-binding proteins, and prostate cancer risk: a prospective study. J Natl Cancer Inst 2000, 92(23):1910-1917.

10. Guo Y, Xu F, Lu T, Duan Z, Zhang Z: Interleukin-6 signaling pathway in targeted therapy for cancer. Cancer Treat Rev 2012, 38(7):904-910.

11. Radhakrishnan P, Chachadi V, Lin MF, Singh R, Kannagi R, Cheng PW: TNFalpha enhances the motility and invasiveness of prostatic cancer cells by stimulating the expression of selective glycosyl- and sulfotransferase genes involved in the synthesis of selectin ligands. Biochem Biophys Res Commun 2011, 409(3):436-441.

12. Flores MB, Rocha GZ, Damas-Souza DM, Osorio-Costa F, Dias MM, Ropelle ER, Camargo JA, de Carvalho RB, Carvalho HF, Saad MJ, Carvalheira JB: Obesity-induced increase in tumor necrosis factor-alpha leads to development of colon cancer in mice. Gastroenterology 2012, 143(3):741-753. e741-744.

13. Hursting SD, Hursting MJ: Growth signals, inflammation, and vascular perturbations: mechanistic links between obesity, metabolic syndrome, and cancer. Arterioscler Thromb Vasc Biol 2012, 32(8):1766-1770.

14. Gallagher EJ, Leroith D: Epidemiology and molecular mechanisms tying obesity, diabetes, and the metabolic syndrome with cancer. Diabetes Care 2013, 36(Suppl 2):S233-S239.

15. Braun S, Bitton-Worms K, LeRoith D: The link between the metabolic syndrome and cancer. Int J Biol Sci 2011, 7(7):1003-1015.

16. Airley RE, Mobasheri A: Hypoxic regulation of glucose transport, anaerobic metabolism and angiogenesis in cancer: novel pathways and targets for anticancer therapeutics. Chemotherapy 2007, 53(4):233-256.

17. Moher D, Liberati A, Tetzlaff J, Altman DG, Group P: Preferred reporting items for systematic reviews and meta-analyses: the PRISMA statement. PLoS Med 2009, 6(7):e1000097.

18. Stocks T, Rapp K, Bjorge T, Manjer J, Ulmer H, Selmer R, Lukanova A, Johansen D, Concin H, Tretli S, Hallmans G, Jonsson H, Stattin P: Blood glucose and risk of incident and fatal cancer in the metabolic syndrome and cancer project (me-can): analysis of six prospective cohorts. PLOS Med 2009, 6(12):e1000201.

19. Haggstrom C, Stocks T, Nagel G, Manjer J, Bjorge T, Hallmans G, Engeland A, Ulmer $\mathrm{H}$, Lindkvist B, Selmer R, Concin H, Tretli S, Jonsson H, Stattin P: Prostate cancer, prostate cancer death, and death from other causes, among men with metabolic aberrations. Epidemiology 2014, 25(6):823-828.

20. Friberg E, Orsini N, Mantzoros CS, Wolk A: Diabetes mellitus and risk of endometrial cancer: a meta-analysis. Diabetologia 2007, 50(7):1365-1374.

21. Larsson SC, Mantzoros CS, Wolk A: Diabetes mellitus and risk of breast cancer: a meta-analysis. Int J Cancer 2007, 121(4):856-862.

22. Jiang Y, Ben Q, Shen H, Lu W, Zhang Y, Zhu J: Diabetes mellitus and incidence and mortality of colorectal cancer: a systematic review and meta-analysis of cohort studies. Eur J Epidemiol 2011, 26(11):863-876.

23. Kulendran M, Salhab M, Mokbel K: Oestrogen-synthesising enzymes and breast cancer. Anticancer Res 2009, 29(4):1095-1109.

24. Harbord RM: Updated stests for small-study effects in meta-analyses. Stata Press 2009, 9(2):197-210.

25. Gwack J, Hwang SS, Ko KP, Jun JK, Park SK, Chang SH, Shin HR, Yoo KY: [Fasting serum glucose and subsequent liver cancer risk in a Korean prospective cohort]. J Prev Med Publ Health = Yebang Uihakhoe chi 2007, 40(1):23-28.

26. Park SM, Lim MK, Shin SA, Yun YH: Impact of prediagnosis smoking, alcohol, obesity, and insulin resistance on survival in male cancer patients: National Health Insurance Corporation Study. J Clin Oncol : Off J Am Soc Clin Oncol 2006, 24(31):5017-5024.

27. Zamboni PF, Simone M, Passaro A, Doh Dalla Nora E, Fellin R, Solini A: Metabolic profile in patients with benign prostate hyperplasia or prostate cancer and normal glucose tolerance. Horm Metab Res 2003, 35(5):296-300.

28. Burzawa J, Schmeler K, Soliman P, Lacour R, Meyer L, Huang M, Bevers M, Frumovitz M, Pustilnik T, Brown J, Anderson M, Ramondetta L, Tortolero-
Luna G, Urbauer D, Zhang Q, Broaddus R, Chang S, Gershenson D, Lu K: Evaluation of insulin resistance among endometrial cancer patients. Gynecol Oncol 2012, 127:S8

29. Loh WJ, North BV, Johnston DG, Godsland IF: Insulin resistance-related biomarker clustering and subclinical inflammation as predictors of cancer mortality during 21.5 years of follow-up. Cancer Causes Control: CCC 2010, 21(5):709-718.

30. Key TJ: Hormones and cancer in humans. Mutat Res 1995, 333(1-2):59-67.

31. Gunter MJ, Hoover DR, Yu H, Wassertheil-Smoller S, Manson JE, Li J, Harris TG, Rohan TE, Xue X, Ho GY, Einstein MH, Kaplan RC, Burk RD, Wylie-Rosett J, Pollak MN, Anderson G, Howard BV, Strickler HD: A prospective evaluation of insulin and insulin-like growth factor-I as risk factors for endometrial cancer. Cancer Epidemiol Biomarkers Prev 2008, 17(4):921-929.

32. Mink PJ, Shahar E, Rosamond WD, Alberg AJ, Folsom AR: Serum insulin and glucose levels and breast cancer incidence: the atherosclerosis risk in communities study. Am J Epidemio/ 2002, 156(4):349-352.

33. Furberg AS, Thune I: Metabolic abnormalities (hypertension, hyperglycemia and overweight), lifestyle (high energy intake and physical inactivity) and endometrial cancer risk in a Norwegian cohort. Int J Cancer 2003, 104(6):669-676.

34. Sung J, Park M, Kim H, Lee C, Park S, Moon W: J Gastroenterol Hepatol 2012 27(418):0815-9319

35. Manjer J, Kaaks R, Riboli E, Berglund G: Risk of breast cancer in relation to anthropometry, blood pressure, blood lipids and glucose metabolism: a prospective study within the Malmo Preventive Project. Eur J Cancer Prev 2001, 10(1):33-42

36. Friedenreich CM, Langley AR, Speidel TP, Lau DC, Courneya KS, Csizmadi I, Magliocco AM, Yasui Y, Cook LS: Case-control study of markers of insulin resistance and endometrial cancer risk. Endocr Relat Cancer 2012, 19(6):785-792.

37. Hubbard JS, Rohrmann S, Landis PK, Metter EJ, Muller DC, Andres R, Carter $H B$, Platz EA: Association of prostate cancer risk with insulin, glucose, and anthropometry in the Baltimore longitudinal study of aging. Urology 2004, 63(2):253-258.

38. Ollberding N, Cheng I, Wilkens L, Henderson B, Pollak M, Kolonel L, Le Marchand $L$ : Genetic variants, prediagnostic circulating levels of insulin-like growth factors, insulin, and glucose and the risk of colorectal cancer: the Multiethnic Cohort study. Cancer Epidemiol Biomarkers Prev 2012, 21(5):810-820.

39. Haggstrom C, Stocks T, Ulmert D, Bjorge T, Ulmer H, Hallmans G, Manjer J, Engeland A, Nagel G, Almqvist M, Selmer R, Concin H, Tretli S, Jonsson H, Stattin P: Prospective study on metabolic factors and risk of prostate cancer. Cancer 2012, 118(24):6199-6206.

40. Borena W, Strohmaier S, Lukanova A, Bjorge T, Lindkvist B, Hallmans G, Edlinger M, Stocks T, Nagel G, Manjer J, Engeland A, Selmer R, Häggström C, Tretli S, Concin H, Jonsson H, Stattin P, Ulmer H: Metabolic risk factors and primary liver cancer in a prospective study of 578,700 adults. Int $J$ Cancer 2012, 131(1):193-200.

41. Peters JL, Sutton AJ, Jones DR, Abrams KR, Rushton L: Contour-enhanced meta-analysis funnel plots help distinguish publication bias from other causes of asymmetry. J Clin Epidemiol 2008, 61(10):991-996.

42. Harbord RM: Updated tests for small effects in meta-analyses. Stata Press 2009, 9(2):197-210

43. Margel D, Urbach DR, Lipscombe LL, Bell CM, Kulkarni G, Austin PC, Fleshner N: Metformin use and all-cause and prostate cancer-specific mortality among men with diabetes. J Clin Oncol 2013, 31(25):3069-3075.

44. Gunter MJ, Hoover DR, Yu H, Wassertheil-Smoller S, Rohan TE, Manson JE, Howard BV, Wylie-Rosett J, Anderson GL, Ho GY, Kaplan RC, Li J, Xue X, Harris TG, Burk RD, Strickler HD: Insulin, insulin-like growth factor-I, endogenous estradiol, and risk of colorectal cancer in postmenopausal women. Cancer Res 2008, 68(1):329-337.

45. Yun JE, Jo I, Park J, Kim MT, Ryu HG, Odongua N, Kim E, Jee SH: Cigarette smoking, elevated fasting serum glucose, and risk of pancreatic cancer in Korean men. Int J Cancer 2006, 119(1):208-212.

46. Muti P, Quattrin T, Grant BJ, Krogh V, Micheli A, Schunemann HJ, Ram M, Freudenheim JL, Sieri S, Trevisan M, Berrino F: Fasting glucose is a risk factor for breast cancer: a prospective study. Cancer Epidemiol Biomarkers Prev 2002, 11(11):1361-1368.

47. Rapp K, Schroeder J, Klenk J, Ulmer H, Concin H, Diem G, Oberaigner W, Weiland SK: Fasting blood glucose and cancer risk in a cohort of more than 140,000 adults in Austria. Diabetologia 2006, 49(5):945-952. 
48. Stattin P, Bjor O, Ferrari P, Lukanova A, Lenner P, Lindahl B, Hallmans G, Kaaks R: Prospective study of hyperglycemia and cancer risk. Diabetes Care 2007, 30(3):561-567

49. Stocks T, Lukanova A, Rinaldi S, Biessy C, Dossus L, Lindahl B, Hallmans G, Kaaks $R$, Stattin P: Insulin resistance is inversely related to prostate cancer: a prospective study in Northern Sweden. Int J Cancer 2007, 120(12):2678-2686

50. Lambe M, Wigertz A, Garmo H, Walldius G, Jungner I, Hammar N: Impaired glucose metabolism and diabetes and the risk of breast, endometrial, and ovarian cancer. Cancer Causes Control: CCC 2011, 22(8):1163-1171.

51. Stocks T, Lukanova A, Johansson M, Rinaldi S, Palmqvist R, Hallmans G, Kaaks R, Stattin P: Components of the metabolic syndrome and colorectal cancer risk; a prospective study. Int J Obes 2008, 32(2):304-314.

52. Ma J, Pollak MN, Giovannucci E, Chan JM, Tao Y, Hennekens CH, Stampfer $\mathrm{MJ}$ : Prospective study of colorectal cancer risk in men and plasma levels of insulin-like growth factor (IGF)-I and IGF-binding protein-3. J Natl Cancer Inst 1999, 91(7):620-625.

53. de Santana IA, Moura GS, Vieira NF, Cipolotti R: Metabolic syndrome in patients with prostate cancer. Sao Paulo Med J 2008, 126(5):274-278.

54. Jun JK, Gwack J, Park SK, Choi YH, Kim Y, Shin A, Chang SH, Shin HR, Yoo $\mathrm{KY}$ : [Fasting serum glucose level and gastric cancer risk in a nested case-control study]. J Prev Med Public Health 2006, 39(6):493-498.

55. Walker K, Bratton DJ, Frost C: Premenopausal endogenous oestrogen levels and breast cancer risk: a meta-analysis. Br J Cancer 2011, 105(9):1451-1457.

56. Darbinian JA, Ferrara AM, Van Den Eeden SK, Quesenberry CP Jr, Fireman B, Habel LA: Glycemic status and risk of prostate cancer. Cancer Epidemio Biomarkers Prev 2008, 17(3):628-635.

57. Berrington de Gonzalez A, Yun JE, Lee SY, Klein AP, Jee SH: Pancreatic cancer and factors associated with the insulin resistance syndrome in the Korean cancer prevention study. Cancer Epidemiol Biomarkers Prev 2008, 17(2):359-364.

58. Ehrmann-Josko A, Sieminska J, Gornicka B, Ziarkiewicz-Wroblewska B, Ziolkowski B, Muszynski J: Impaired glucose metabolism in colorectal cancer. Scand J Gastroenterol 2006, 41(9):1079-1086.

59. Ozasa K, Ito Y, Suzuki K, Watanabe Y, Kojima M, Suzuki S, Tokudome S, Tamakoshi K, Toyoshima H, Kawado M, Hashimoto S, Hayakawa N, Wakai K, Tamakoshi A, JACC Study Group: Glucose intolerance and colorectal cancer risk in a nested case-control study among Japanese People. J Epidemiol 2005, 15(Suppl 2):S180-S184.

60. Tsushima M, Nomura AM, Lee J, Stemmermann GN: Prospective study of the association of serum triglyceride and glucose with colorectal cancer. Dig Dis Sci 2005, 50(3):499-505.

61. Suehiro T, Matsumata T, Shikada Y, Sugimachi K: Hyperinsulinemia in patients with colorectal cancer. Hepatogastroenterology 2005, 52(61):76-78.

62. Krajcik RA, Borofsky ND, Massardo S, Orentreich N: Insulin-like growth factor I (IGF-I), IGF-binding proteins, and breast cancer. Cancer Epidemiol Biomarkers Prev 2002, 11(12):1566-1573.

63. Gapstur SM, Gann PH, Lowe W, Liu K, Colangelo L, Dyer A: Abnormal glucose metabolism and pancreatic cancer mortality. JAMA 2000, 283 (19):2552-2558.

64. Spyridopoulos TN, Dessypris N, Antoniadis AG, Gialamas S, Antonopoulos CN, Katsifoti K, Adami HO, Chrousos GP, Petridou ET, Obesity and Cancer Oncology Group: Insulin resistance and risk of renal cell cancer: a case-control study. Hormones 2012, 11(3):308-315.

65. Singh S, Gahlot A, Pandey M, Pradhan S: Endocr Rev 2012, 33/3:0163-0769X.

66. Simon D, Lange C, Charles M: Balkau B: Diabetes care 2011, 60(A359):0012-1797.

67. Saydah SH, Loria CM, Eberhardt MS, Brancati FL: Abnormal glucose tolerance and the risk of cancer death in the United States. Am J Epidemiol 2003, 157(12):1092-1100.

68. Nilsen TI, Vatten $\amalg$ : Prospective study of colorectal cancer risk and physical activity, diabetes, blood glucose and BMl: exploring the hyperinsulinaemia hypothesis. Br J Cancer 2001, 84(3):417-422.

69. Lawlor DA, Smith GD, Ebrahim S: Hyperinsulinaemia and increased risk of breast cancer: findings from the British Women's Heart and Health Study. Cancer Causes Control : CCC 2004, 15(3):267-275.

70. Saydah SH, Platz EA, Rifai N, Pollak MN, Brancati FL, Helzlsouer KJ: Association of markers of insulin and glucose control with subsequent colorectal cancer risk. Cancer Epidemiol Biomarkers Prev 2003, 12(5):412-418
71. Nandeesha $H$, Koner BC, Dorairajan LN: Altered insulin sensitivity, insulin secretion and lipid profile in non-diabetic prostate carcinoma. Acta Physiol Hung 2008, 95(1):97-105.

72. Online calculator tool. http://www.socbdr.org/rds/authors/ unit_tables_conversions_and_genetic_dictionaries/conversion_in_si_units.

73. Alberti $K G$, Zimmet PZ: The reference is : Definition, diagnosis and classification of diabetes mellitus and its complications. Part 1: diagnosis and classification of diabetes mellitus provisional report of a WHO consultation. Diabet Med 1998, 15(7):539-53.

74. Smith GD, Gunnell D, Holly J: Cancer and insulin-like growth factor-I. A potential mechanism linking the environment with cancer risk. BMJ 2000, 321(7265):847-848.

75. Hankinson SE, Willett WC, Colditz GA, Hunter DJ, Michaud DS, Deroo B, Rosner B, Speizer FE, Pollak M: Circulating concentrations of insulin-like growth factor-I and risk of breast cancer. Lancet 1998, 351(9113):1393-1396.

76. Chan JM, Stampfer MJ, Giovannucci E, Gann PH, Ma J, Wilkinson P, Hennekens CH, Pollak M: Plasma insulin-like growth factor-I and prostate cancer risk: a prospective study. Science 1998, 279(5350):563-566.

77. Yun SJ, Min BD, Kang HW, Shin KS, Kim TH, Kim WT, Lee SC, Kim WJ: Elevated insulin and insulin resistance are associated with the advanced pathological stage of prostate cancer in Korean population. $J$ Korean Med Sci 2012, 27(9):1079-1084.

78. Albanes D, Weinstein SJ, Wright ME, Mannisto S, Limburg PJ, Snyder K, Virtamo J: Serum insulin, glucose, indices of insulin resistance, and risk of prostate cancer. J Natl Cancer Inst 2009, 101(18):1272-1279.

79. Chung YW, Han DS, Park YK, Son BK, Paik CH, Lee HL, Jeon YC, Sohn JH: Association of obesity, serum glucose and lipids with the risk of advanced colorectal adenoma and cancer: a case-control study in Korea. Dig Liver Dis 2006, 38(9):668-672.

80. Hsing AW, Gao YT, Chua S Jr, Deng J, Stanczyk FZ: Insulin resistance and prostate cancer risk. J Natl Cancer Inst 2003, 95(1):67-71.

81. Wulaningsih W, Holmberg L, Garmo H, Zethelius B, Wigertz A, Carroll P, Lambe M, Hammar N, Walldius G, Jungner I, Van Hemelrijck M: Serum glucose and fructosamine in relation to risk of cancer. PLoS One 2013, 8(1):e54944.

82. Cust AE, Kaaks R, Friedenreich C, Bonnet F, Laville M, Tjonneland A, Olsen A, Overvad K, Jakobsen MU, Chajes V, Clavel-Chapelon F, Boutron-Ruault MC, Linseisen J, Lukanova A, Boeing H, Pischon T, Trichopoulou A, Christina B, Trichopoulos D, Palli D, Berrino F, Panico S, Tumino R, Sacerdote C, Gram IT, Lund E, Quirós JR, Travier N, Martínez-García C, Larrañaga N, et al: Metabolic syndrome, plasma lipid, lipoprotein and glucose levels, and endometrial cancer risk in the European Prospective Investigation into Cancer and Nutrition (EPIC). Endocr Relat Cancer 2007, 14(3):755-767.

83. Limburg PJ, Stolzenberg-Solomon RZ, Vierkant RA, Roberts K, Sellers TA, Taylor PR, Virtamo J, Cerhan JR, Albanes D: Insulin, glucose, insulin resistance, and incident colorectal cancer in male smokers. Clin Gastroenterol Hepatol 2006, 4(12):1514-1521.

84. Stolzenberg-Solomon RZ, Graubard BI, Chari S, Limburg P, Taylor PR, Virtamo J, Albanes D: Insulin, glucose, insulin resistance, and pancreatic cancer in male smokers. JAMA 2005, 294(22):2872-2878.

85. Yamada K, Araki S, Tamura M, Sakai I, Takahashi Y, Kashihara H, Kono S: Relation of serum total cholesterol, serum triglycerides and fasting plasma glucose to colorectal carcinoma in situ. Int J Epidemiol 1998, 27(5):794-798

86. Schoen RE, Tangen CM, Kuller LH, Burke GL, Cushman M, Tracy RP, Dobs A, Savage PJ: Increased blood glucose and insulin, body size, and incident colorectal cancer. J Natl Cancer Inst 1999, 91(13):1147-1154.

87. Zhang Y, Liu Z, Yu X, Zhang X, Lu S, Chen X, Lu B: The association between metabolic abnormality and endometrial cancer: a large case-control study in China. Gynecol Oncol 2010, 117(1):41-46.

88. Gunter MJ, Hoover DR, Yu H, Wassertheil-Smoller S, Rohan TE, Manson JE, Li J, Ho GY, Xue X, Anderson GL, Kaplan RC, Harris TG, Howard BV, WylieRosett J, Burk RD, Strickler HD: Insulin, insulin-like growth factor-I, and risk of breast cancer in postmenopausal women. J Natl Cancer Inst 2009, 101(1):48-60.

89. Sieri S, Muti P, Claudia A, Berrino F, Pala V, Grioni S, Abagnato CA, Blandino G, Contiero P, Schunemann HJ, Krogh V: Prospective study on the role of glucose metabolism in breast cancer occurrence. Int J Cancer 2012, 130(4):921-929.

90. Van Hemelrijck M, Garmo H, Hammar N, Jungner I, Walldius G, Lambe M, Holmberg L: The interplay between lipid profiles, glucose, BMI and risk of 
kidney cancer in the Swedish AMORIS study. Int J Cancer 2012, 130(9):2118-2128.

91. Van Hemelrijck M, Garmo H, Holmberg L, Walldius G, Jungner I, Hammar N, Lambe M: Prostate cancer risk in the Swedish AMORIS study: the interplay among triglycerides, total cholesterol, and glucose. Cancer 2011, 117(10):2086-2095.

92. Chao LT, Wu CF, Sung FY, Lin CL, Liu CJ, Huang CJ, Tsai KS, Yu MW: Insulin, glucose and hepatocellular carcinoma risk in male hepatitis $B$ carriers: results from 17-year follow-up of a population-based cohort. Carcinogenesis 2011, 32(6):876-881.

93. Pollak M: Insulin and insulin-like growth factor signalling in neoplasia. Nat Rev Cancer 2008, 8(12):915-928.

94. Rose DP, Vona-Davis L: The cellular and molecular mechanisms by which insulin influences breast cancer risk and progression. Endocrine-related cancer 2012, 19(6):R225-R241.

95. Huxley R, Ansary-Moghaddam A, Berrington de Gonzalez A, Barzi F, Woodward M: Type-II diabetes and pancreatic cancer: a meta-analysis of 36 studies. Br J Cancer 2005, 92(11):2076-2083.

96. Grundmark B, Garmo H, Loda M, Busch C, Holmberg L, Zethelius B: The metabolic syndrome and the risk of prostate cancer under competing risks of death from other causes. Cancer Epidemiol Biomarkers Prev 2010, 19(8):2088-2096.

97. Danaei G, Vander Hoorn S, Lopez AD, Murray CJ, Ezzati M, Comparative Risk Assessment collaborating g: Causes of cancer in the world: comparative risk assessment of nine behavioural and environmental risk factors. Lancet 2005, 366(9499):1784-1793.

doi:10.1186/1471-2407-14-985

Cite this article as: Crawley et al:: Serum glucose and risk of cancer: a meta-analysis. BMC Cancer 2014 14:985.

\section{Submit your next manuscript to BioMed Central and take full advantage of:}

- Convenient online submission

- Thorough peer review

- No space constraints or color figure charges

- Immediate publication on acceptance

- Inclusion in PubMed, CAS, Scopus and Google Scholar

- Research which is freely available for redistribution 